\title{
Establishment and Characterization of a Novel Human Clear- cell Sarcoma of Soft-tissue Cell Line, RSAR001, Derived from Pleural Effusion of a Patient with Pleural Dissemination
}

\author{
MICHIYUKI HAKOZAKI ${ }^{1,2}$, HIROSUMI TAMURA ${ }^{1}$, YUU DOBASHI $^{1}$, AKI YOSHIDA $^{3}$, \\ KOUKI KATO ${ }^{4}$, TAKAHIRO TAJINO ${ }^{2,5}$, HITOSHI YAMADA $^{2}$, YOICHI KANEUCHI ${ }^{2}$, KIYOAKI KATAHIRA $^{1}$, \\ JUNJI EZAKI ${ }^{1}$, SATOSHI WAGURI ${ }^{1}$, SHINICHI KONNO ${ }^{2}$ and SHINYA WATANABE ${ }^{1}$ \\ ${ }^{1}$ Medical-Industrial Translational Research Center, Fukushima Global Medical Science Center, \\ Fukushima Medical University, Fukushima, Japan; \\ ${ }^{2}$ Department of Orthopaedic Surgery, Fukushima Medical University School of Medicine, Fukushima, Japan; \\ ${ }^{3}$ Department of Orthopaedic Surgery, Okayama University Graduate School of Medicine, \\ Dentistry, and Pharmaceutical Sciences, Okayama, Japan; \\ ${ }^{4}$ Center for Laboratory Animal Science, National Defense Medical College, Saitama, Japan; \\ ${ }^{5}$ Division of Orthopaedic Surgery, Southern Tohoku Fukushima Hospital, Fukushima, Japan
}

\begin{abstract}
Background/Aim: Clear cell sarcoma (CCS) of soft tissue is exceedingly rare and frequently exhibits aggressive behavior. Toward the goals of improving the aggressive course and poor prognosis of CCS, and establish new therapeutic methods, molecular genetic and biological characterizations of CCS are required. Materials and Methods: A new human CCS cell line (designated RSAR001) was established from the pleural effusion of a 44-year-old man with multiple lung metastases and pleural dissemination. The cell line and its xenograft were characterized including their morphology, immunohistochemistry, cytogenetic analysis, reverse transcriptionpolymerase chain reaction, direct sequencing analysis, and fluorescence in situ hybridization analysis. Results: The cell line has been maintained for over 12 months with more than 50 passages. RSAROO1 cells exhibited a fascicular or diffuse growth pattern of short spindle- or oval-shaped cells with clear cytoplasm in heterotransplanted tumor, that was similar to the primary tumor. Immunophenotypically, RSAROO1 cells in vitro and in vivo exhibited almost the same characteristics as the
\end{abstract}

This article is freely accessible online.

Correspondence to: Dr. Michiyuki Hakozaki, Department of Orthopaedic Surgery, Fukushima Medical University School of Medicine, 1 Hikarigaoka, Fukushima-shi, Fukushima 960-1295, Japan. Tel: +81 245471276, Fax: +81 245485505, e-mail: paco@fmu.ac.jp

Key Words: Clear cell sarcoma of soft tissue, cell line, xenograft, EWSR1-ATF 1 type 1 chimeric fusion gene, fluorescence in situ hybridization. primary tumor. Cytogenetic analyses revealed a translocation, $t(12 ; 22)(q 13 ; q 12)$. Reverse transcription-polymerase chain reaction and direct sequencing analysis detected transcripts of the Ewing sarcoma breakpoint region 1-activating transcription factor 1 (EWSR1-ATF1) type 1 fusion gene. Fluorescence in situ hybridization using a break-apart probe for the EWSRI gene on $22 q 12$ showed a rearrangement. Conclusion: These findings indicate that the RSAROO1 cell line harbors EWSR1ATF1 type 1 chimeric fusion gene, which is specific to CCS. RSAR001 cells might be useful for investigating biological behaviors and developing new treatments such as moleculartargeting antitumor drugs or immunological drugs for CCS.

Clear cell sarcoma (CCS) of soft tissue, also called malignant melanoma of soft parts, is an extremely rare softtissue sarcoma with uncertain differentiation that affects young adults between the ages of 20 and 40 years $(1,2)$. CCS most frequently occurs in the foot and ankle (approximately $40 \%$ of the reported cases) $(1,2)$. Although CCS usually grows slowly, it frequently exhibits aggressive behavior, resistance to multi-agent chemotherapy and radiation therapy, and fatal metastasis. The overall 5-, 10-, and 20-year survival rates are $67 \%, 33 \%$, and $10 \%$, respectively (1). Therefore, in order to improve the aggressive course and unfavorable prognosis of CCS over the long term, new treatments including molecular-targeting drugs or immunological drugs based on molecular, genetic, and immunobiological characterization of CCS are required.

To the best of our knowledge, only a few human CCS cell lines have been established (3-16). Molecular, genetic and biological characterizations of CCS using in vitro and in vivo 
models are desired. To clarify the biological behavior of CCS, we established and characterized a new CCS cell line, RSAR001, derived from the pleural effusion of a patient with multiple lung metastases and pleural dissemination.

\section{Materials and Methods}

The patient's clinical history. A 20-year-old Japanese man with no remarkable past medical history was referred to our hospital after marginal resection for a primary soft-tissue tumor of the right ankle at his primary hospital. Since the resected tumor was pathologically diagnosed as synovial sarcoma, additional wide resection followed by six courses of chemotherapy with vincristine and high-dose methotrexate was performed at our hospital. Eighteen years after the primary surgical treatment, multiple lung metastases were found. Light microscopy of the biopsy specimens from the metastatic lung tumor showed diffuse proliferation of short spindleor oval-shaped cells with melanin (Figure 1A). The tumor cells exhibited atypical nuclei, and mitotic figures were frequently seen. Immunohistochemically, tumor cells were positive for vimentin, $\mathrm{S}$ 100 protein (Figure 1B), human melanin black-45 (HMB-45) (Figure 1C), and melan-A (Figure 1D), but negative for AE1/AE3, alpha-smooth muscle actin ( $\alpha$-SMA), and desmin (Table I). The characteristics revealed by light microscopy and immunohistochemistry led us to change the diagnosis from synovial sarcoma to CCS. Notwithstanding the combined treatment with surgery, chemotherapy or proton therapy, metastatic lung tumors slowly grew larger. The patient died of his disease at the age of 44 years, 62 months after the appearance of lung metastases.

Establishment of the RSAR001 cell line. Tumor cells were collected from the pleural effusion obtained approximately 1 month prior to the patient's death. The tumor cells were collected by centrifugation and rinsed with Hanks' balanced salt solution with $1 \%$ penicillinstreptomycin mixed solution (Nacalai Tesque, Kyoto, Japan). Cells were cultured at an initial density of $1.0 \times 10^{6}$ viable cells $/ \mathrm{ml}$ in RPMI-1640 medium (Fujifilm Wako Pure Chemical, Osaka, Japan) supplemented with $15 \%$ heat-inactivated fetal bovine serum (Biowest, Nuaillé, France). The cells were then inoculated into 100$\mathrm{mm}$ plastic dishes (Greiner Bio-One, Kremsmünster, Austria) and incubated at $37^{\circ} \mathrm{C}$ in a humidified atmosphere with $5 \% \mathrm{CO}_{2}$. The culture medium was changed twice per week. To harvest and transfer the cell line, the cells were treated with trypsin-EDTA solution (Lonza, Basel, Switzerland) after they reached a subconfluent state. The cell line has been maintained for over 12 months under these culture conditions and was designated as RSAR001.

Morphological study. The growth and morphology of RSAR001 cells in vitro was observed by using an inverted microscope. Morphological characteristics were further determined by hematoxylin-eosin staining on paraffin-embedded sections.

Immunohistochemistry. An imunohistochemical analysis was performed on the primary tumor, RSAR001 cells at the 49th passage, and heterotransplanted tumors by the streptavidin-biotin complex method. The antibodies used in this study were against S-100 protein (polyclonal; Roche Diagnostics, Indianapolis, IN, USA), HMB45 (clone HMB45; Leica Biosystems, Wetzlar, Germany), melan-A (clone A103; Leica Biosystems), neuron-specific enolase (NSE)
Table I. Immunohistochemical reactivity of primary tumor and RSAR001 cells in vitro and from transplanted tumor.

\begin{tabular}{lccc}
\hline & & \multicolumn{2}{c}{ RSAR001 } \\
\cline { 3 - 4 } Antibody & Primary tumor & In vitro & In vivo \\
\hline S-100 protein & $3+$ & $3+$ & $3+$ \\
HMB-45 & $1+$ & $4+$ & $3+$ \\
Melan-A & $2+$ & $3+$ & $3+$ \\
NSE & NT & $3+$ & $4+$ \\
AE1/AE3 & - & - & - \\
Desmin & - & - & - \\
$\alpha$-SMA & - & - & - \\
\hline
\end{tabular}

- , Negative; $1+,<10 \%$ positively stained cells; $2+, 10-50 \%$ positive cells; $3+,>50-90 \%$ positively stained cells; $4+,>90 \%$ positively stained cells. NT, not tested; HMB-45, human melanin black-45; NSE, neuronspecific enolase; EMA, epithelial membrane antigen; $\alpha$-SMA, $\alpha$-smooth muscle actin.

(clone 22C9; Leica Biosystems), AE1/AE3 (clones AE1/AE3/PCK26; Roche Diagnostics), desmin (clone DE-R-11, Leica, Biosystems), and $\alpha$-SMA (clone 1A4; Dako, Glostrup, Denmark).

Cell population-doubling time. In order to determine the doubling time, RSAR001 cells were seeded at the 55th passage on six-well plastic plates (Greiner Bio-One) with fresh culture medium. Cell growth was measured by determination of the cell density using a CloneSelect $^{\mathrm{TM}}$ Imager system (Molecular Devices, Sunnyvale, CA, USA) for 9 consecutive days.

Heterotransplantation. A NOG mouse (NOD.Cg-Prkdc scid Il2rgtmlSug/ ShiJic, male; 8 weeks old) was used for the heterotransplantation study. NOG mouse was developed by the Central Institute for Experimental Animals (Kanagawa, Japan) (17). The mouse was housed in a plastic cage in a pathogen-free state, at a temperature of $22 \pm 1^{\circ} \mathrm{C}$ with $55 \pm 5 \%$ humidity, and a 12 -h light/12-h dark cycle. The mouse was administered a single subcutaneous injection of $8.0 \times 10^{6}$ cells at the 43rd passage from cultured cells in the log phase of growth. The mouse was maintained in a pathogen-free environment and carefully observed after heterotransplantation.

Cytogenetics. The karyotype analysis of RSAR001 cells at the 54th passage was performed commercially by SRL (Tokyo) using the trypsin G-banding technique.

RNA extraction, cDNA synthesis, reverse transcription-polymerase chain reaction (RT-PCR) analysis, and direct sequencing analyses for mRNA expression of specific fusion gene. Total RNA from RSAR001 cells at the 54th passage was isolated using ISOGEN reagent (Fujifilm Wako Pure Chemical) according to the manufacturer's protocol. One microgram of RNA was reversetranscribed to cDNA using a ReverTra Ace qPCR RT Kit (Toyobo, Osaka, Japan) according to the manufacturer's protocol. Aliquots of cDNA $(1.0 \mu \mathrm{l})$ were amplified using Takara Ex Taq HS polymerase (Takara Bio, Shiga, Japan) in a total volume of $50 \mu$.

For the detection of mRNA of Ewing sarcoma breakpoint region 1-activating transcription factor 1 (EWSR1-ATF 1$)$ fusion gene, PCR was performed as follows: denaturing at $94^{\circ} \mathrm{C}$ for $10 \mathrm{~min}$ 


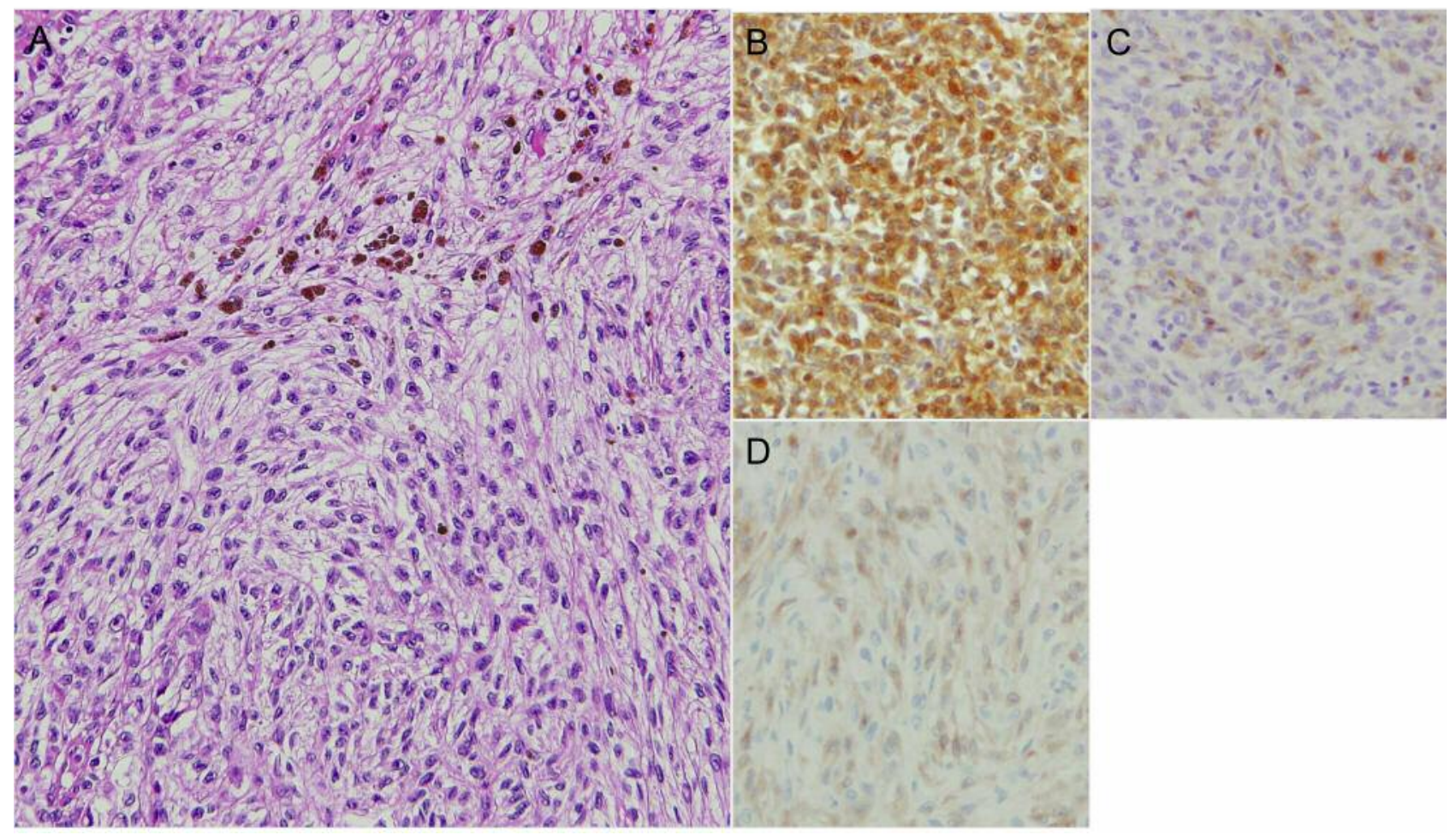

Figure 1. Histology of the metastatic lung tumor. The tumor cells exhibited diffuse proliferation of short spindle- or oval-shaped cells with melanin expression (A) (hematoxylin and eosin, $\times 200$ ). Immunohistochemically the tumor cells were positive for S-100 protein (B), human melanin black-45 $(C)$, and melan- $A(D)$ (immunoperoxidase stain, $\times 200$ ).

A

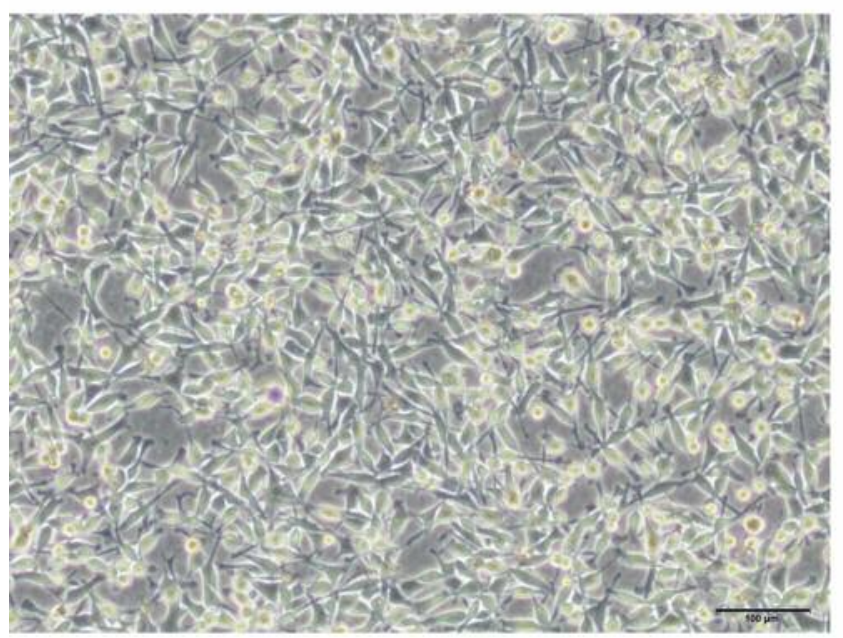

B

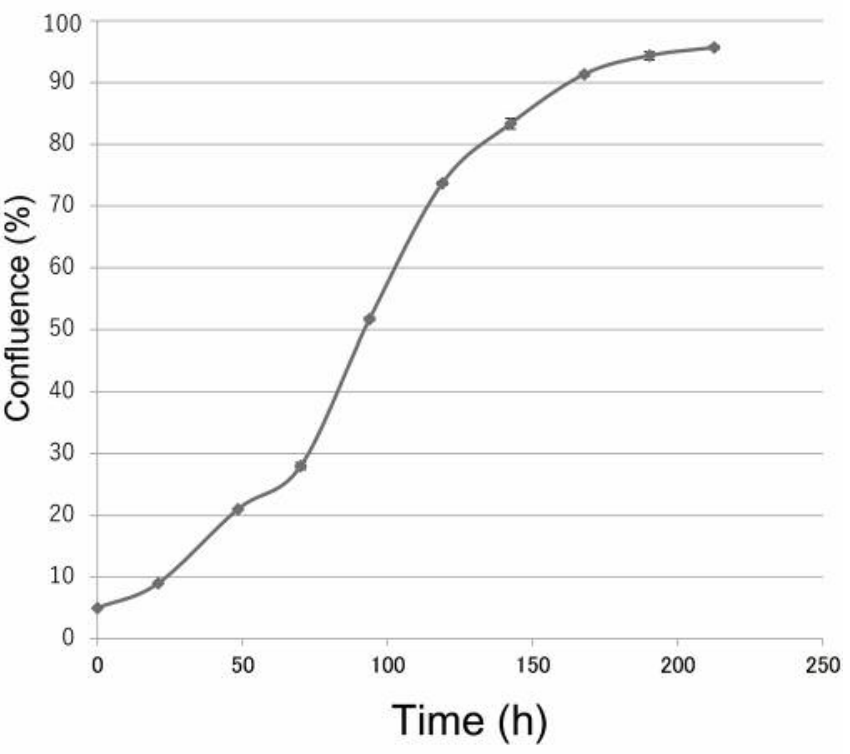

Figure 2. A: Inverted microscopy of RSAR001 cells in vitro (43rd passage). Adherent cultured cells were found to be atypical, small, polygonal or short spindle-shaped without contact inhibition $($ bar $=100 \mu \mathrm{m})$. B: The doubling time of RSAR001 cell line was approximately $35.0 \mathrm{~h}$. 


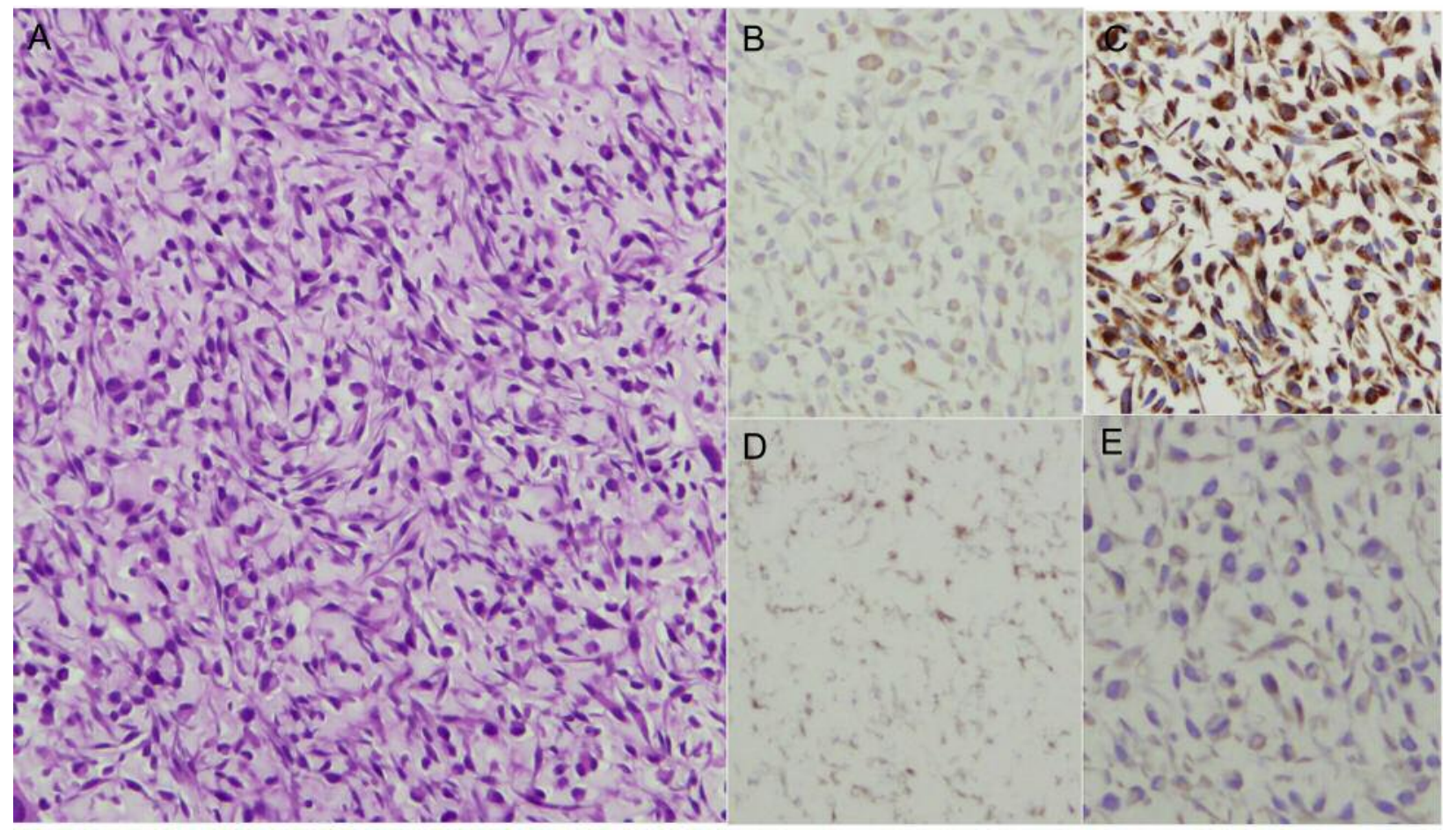

Figure 3. Microscopically, RSAR001 cells comprised small, polygonal or short spindle-shaped cells (A) (hematoxylin and eosin, x200). RSAR001 cells were immunohistochemically positive for $S$-100 protein $(B)$, human melanin black-45 (C), melan-A (D) and neuron-specific enolase (E) (immunoperoxidase stain, $\times 200$ ).

followed by 35 cycles of amplification $\left(95^{\circ} \mathrm{C}\right.$ for $10 \mathrm{~s}, 60^{\circ} \mathrm{C}$ for $20 \mathrm{~s}$, and $72^{\circ} \mathrm{C}$ for $20 \mathrm{~s}$ ) and a 10 -min extension at $72^{\circ} \mathrm{C}$ in a thermal cycler (TProfessional TRIO Thermocycler; Biometra, Göttingen, Germany). The sequencing primers were as follows: EWSex7-F2: TATAGCCAACAGAGCAGCAGC, and ATF1R2: CTGTAAGG CTCCATTTGGGGC (18). These primers were obtained from Sigma-Aldrich Japan (Hokkaido, Japan). The PCR reaction products were electrophoresed through $2 \%$ agarose gels containing $0.2 \mathrm{mg} / \mathrm{ml}$ ethidium bromide. The PCR product was cut and purified with a QIAquick Gel Extraction Kit (Qiagen, Hilden, Germany). Products were directory sequenced with the use of a Big-Dye Terminator v3.1 Cycle sequencing kit (Applied Biosystems, Carlsbad, CA, USA) following the manufacturer's instructions. The oligonucleotide sequences of EWSR1-ATF1 fusion gene were then analyzed using a sequencer and the sequences compared with the germline sequences recorded in the GenBank database.

Fluorescence in situ hybridization (FISH) analysis. The FISH analysis for EWSR1 gene rearrangement was performed commercially on RSAR001 cells at the 54th passage by SRL.

Ethics statement. This study was approved by the Ethical Review Committee of Fukushima Medical University (no. 1765). Written informed consent for study inclusion was obtained from the patient and his younger brother. The animal experiments in the present study were approved by the Institutional Animal Care and Use Committee of Fukushima Medical University (no. 25028).

\section{Results}

Establishment of the RSAROO1 cell line. We established a new human CCS cell line (RSAR001) from the pleural effusion of a patient with multiple metastases of CCS (Figure 2A). The doubling time of this cell line was approximately $35.0 \mathrm{~h}$ (Figure 2B). The cell line has been stably maintained for more than 50 passages over a period of more than 12 months. Cultured cells comprised small, polygonal or short-spindleshaped cells (Figure 3A). Loss of contact inhibition was observed. Immunohistochemically, cultured cells were positive for S-100 protein (Figure 3B), HMB45 (Figure 3C), melan-A (Figure 3D) and NSE (Figure 3E), but negative for AE1/AE3, desmin, and $\alpha$-SMA (Table I).

Heterotransplantation. The RSAR001 cell line was successfully heterotransplanted into a NOG mouse. The NOG mouse was given a single subcutaneous injection of RSAR001 cells; a tumor with a diameter of approximately $7 \mathrm{~mm}$ developed 13 weeks after inoculation. The cut surface of the xenografted tumor was solid and white. Under light microscopy, the heterotransplanted tumor of the NOG mouse showed a morphological pattern similar to that of the primary tumor (metastatic lung tumor) (Figure 4A). The heterotransplanted 


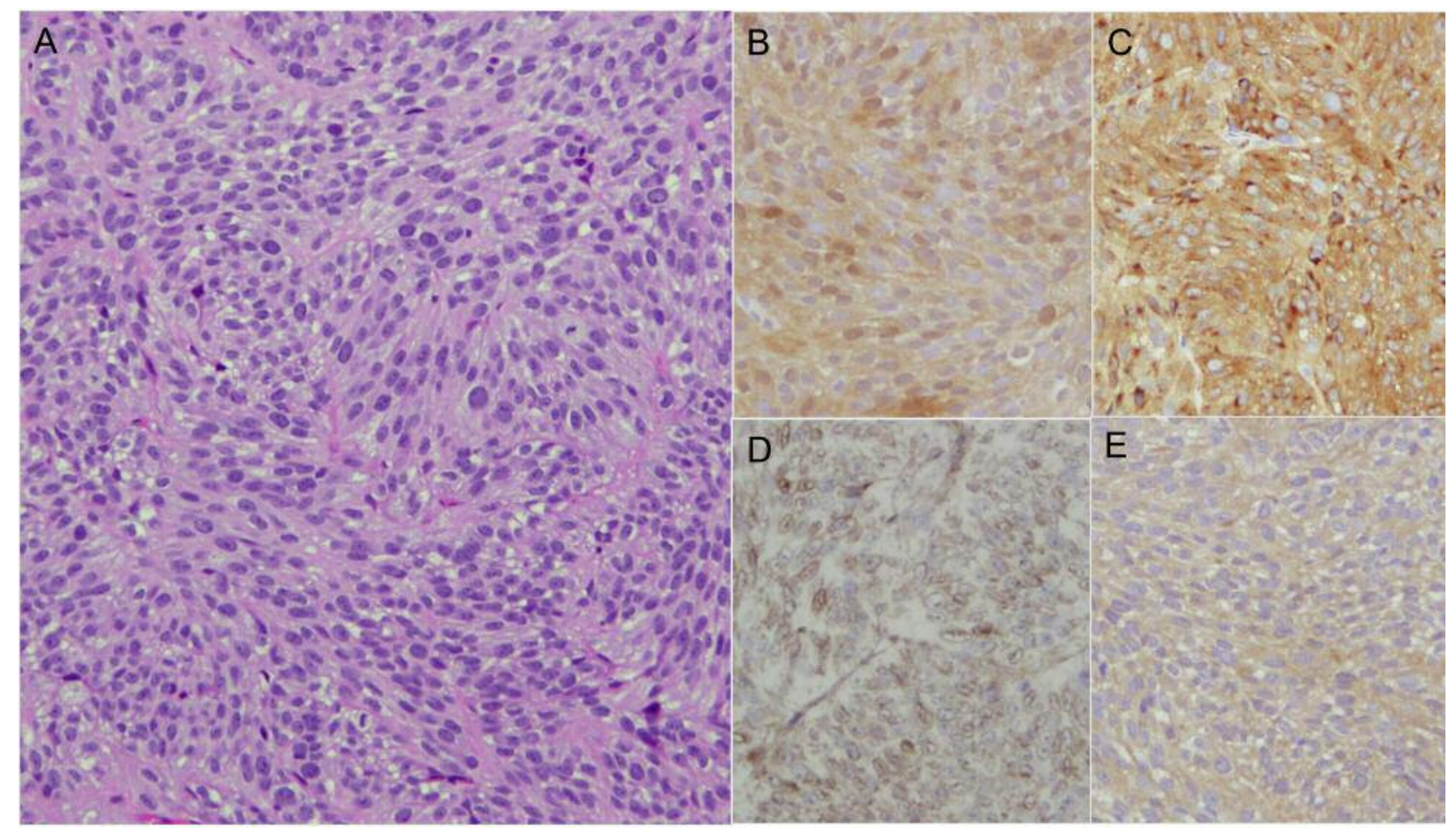

Figure 4. On microscopic findings of heterotransplanted tumor in the NOG mouse, RSAR001 cells from the NOG mouse exhibited a morphological pattern that was similar to that of the primary tumor $(A)(H \& E, \times 200)$. RSAR001 cells displayed positive immunohistochemical reaction for $S-100$ protein $(B)$, human melanin black-45 (C), melan-A (D) and neuron-specific enolase (E) (immunoperoxidase stain, $\times 200)$.

tumor cells exhibited almost the same immunophenotype as that of the primary tumor cells (Figure 4B-E) (Table I).

Cytogenetics. The karyotype analysis of G-banded chromosomes for RSAR001 cells revealed the following composite karyotype: $61<2 \mathrm{n}>$ (modal number: 61), XY, $+\operatorname{der}(1 ; 9)(\mathrm{q} 10 ; \mathrm{p} 10) \times 2, \quad \mathrm{t}(1 ; 2)(\mathrm{p} 31 ; \mathrm{p} 23) \times 2, \quad+\operatorname{add}(3)(\mathrm{p} 11)$, $? \mathrm{t}(3 ; 17)(\mathrm{p} 21 ; \mathrm{q} 23) \times 2, \quad+\operatorname{der}(7) \mathrm{t}(7 ; 8)(\mathrm{p} 11.2 ; \mathrm{q} 11.2) \times 2, \quad+8$, $+\mathrm{i}(8)(\mathrm{q} 10), \operatorname{add}(9)(\mathrm{p} 11) \times 2, \mathrm{t}(12 ; 22)(\mathrm{q} 13 ; \mathrm{q} 12),+14,+15,+16$, $+17,+19, \operatorname{der}(22) \mathrm{t}(12 ; 22),+$ mar1, +mar2, +mar3 (Figure 5).

$R T-P C R$ and direct sequencing analyses for specific fusion gene mRNA expression. EWSR1-ATF1 type 1 chimeric fusion gene transcript mRNA, a specific gene for CCS, was detected in the RSAR001 cells (Figure 6A and B).

FISH analysis for split signal of EWSRI gene. In the RSAR001 cell line, the FISH analysis using a break-apart probe specific to the EWSRI gene on $22 \mathrm{q} 12$ showed a rearrangement in 100 of 100 nuclei assessed (Figure 6C).

\section{Discussion}

We established the RSAR001 cell line from the pleural effusion of a patient with a CCS. RSAR001 cells exhibited typical morphological characteristics of CCS in a heterotransplanted tumor, with diffuse proliferation of short spindle- or oval-shaped cells. The immunohistochemical findings of the RSAR001 cell line both in vitro and in vivo also showed a pattern that was similar to that of the primary tumor cells. Moreover, several genetic findings showed that the RSAR001 cell line harbored EWSRI-ATF1 type 1 chimeric fusion gene, which is specific to CCS and is the most common type of EWSRI-ATF 1 chimeric fusion gene $(1,2)$.

To the best of our knowledge, 15 human CCS cell lines have been reported to date (Table II) (3-16). Among these CCS cell lines, nine harbor EWSRI-ATF1 type 1 fusion gene (3, 6, 8$10,13,14,16)$, two harbor type 2 fusion gene $(11,15)$, and one harbors type 3 fusion gene (12). Heterotransplantation into immunodeficient model mice was reported for only three of the previously identified nine cell lines with EWSRI-ATF1 type 1 fusion gene $(3,8,14)$. The value of RSAR001, the 16th human CCS cell line with EWSR1-ATF1 type 1, is its utility for both in vitro and in vivo experiments as well as its rarity.

Most cases of CCS exhibit slowly growing but aggressive behavior. Because they show resistance to multi-agent chemotherapy and radiation therapy, a wide resection with an adequate margin is the only established treatment for CCS at this time (19). Thus, distant metastases, which often appear long after surgery for the primary tumor, may be fatal if they cannot 


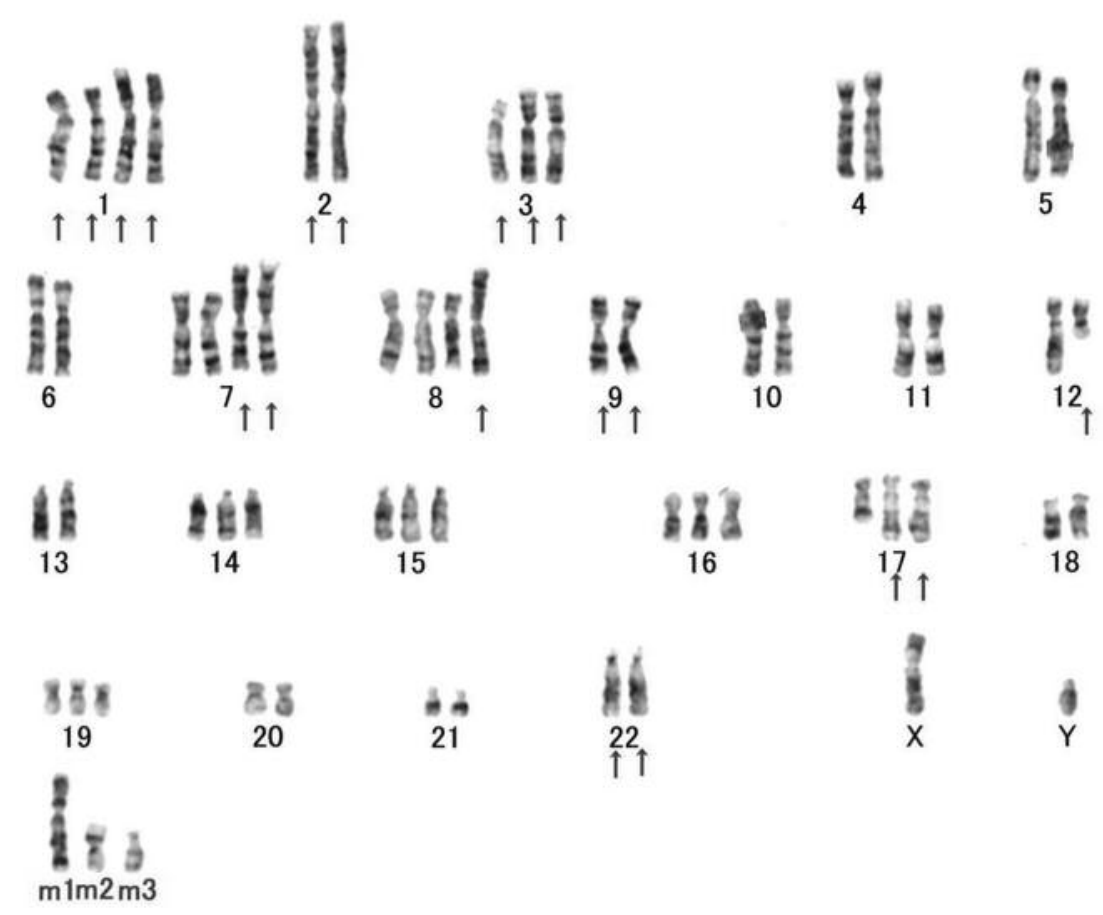

Figure 5. Representative G-banded karyotype of the RSAR001 cell line at the 54th passage, exhibiting the following abnormal complement: $61<2 n>$ (modal number: 61), XY, $+\operatorname{der}(1 ; 9)(q 10 ; p 10) \times 2, t(1 ; 2)(p 31 ; p 23) \times 2,+a d d(3)(p 11), ? t(3 ; 17)(p 21 ; q 23) \times 2,+\operatorname{der}(7) t(7 ; 8)(p 11.2 ; q 11.2) \times 2,+8,+i(8)(q 10)$, $\operatorname{add}(9)(p 11) \times 2, t(12 ; 22)(q 13 ; q 12),+14,+15,+16,+17,+19, \operatorname{der}(22) t(12 ; 22),+$ mar1, + mar2, + mar 3 . Arrows indicate the abnormal chromosomes.

Table II. Previously established clear-cell sarcoma of soft tissue cell lines.

\begin{tabular}{|c|c|c|c|c|c|}
\hline No. & Cell line (Ref.) & Patient's age, years/gender & Tumor site & EWSR1-ATF1 & Heterotransplantation \\
\hline 1 & SU-CCS1 (3) & $16 / \mathrm{F}$ & Heel & Type 1 & Yes \\
\hline 2 & HS-MM (4) & $39 / \mathrm{M}$ & Knee & NA & Yes \\
\hline 3 & NCS-1 (5) & $38 / \mathrm{M}$ & Foot & NA & Yes \\
\hline 4 & DTC1 (6) & NA & Chest wall & Type 1 & NA \\
\hline 5 & MST-1 (7) & $14 / \mathrm{F}$ & Knee & NA & Yes \\
\hline 6 & Kao (8) & $9 / \mathrm{F}$ & Thigh & Type 1 & Yes \\
\hline 7 & MP-CCS-SY (9) & $17 / \mathrm{F}$ & Ankle & Type 1 & NA \\
\hline 8 & GG-62 (10) & $25 / \mathrm{F}$ & Lower leg & Type 1 & NA \\
\hline 9 & UM-CCS-1 (11) & $60 / \mathrm{F}$ & Thigh & Type 2 & Yes (in vivo only) \\
\hline 10 & KAS (12) & $25 / M$ & Lymph node metastasis & Type 3 & Yes \\
\hline 11 & MST2 (13) & $60 / \mathrm{M}$ & Knee & Type 1 & NA \\
\hline 12 & MST3 (13) & $34 / \mathrm{M}$ & Groin & Type 1 & NA \\
\hline 13 & CCS292 (14) & NA & NA & Type 1 & Yes \\
\hline 14 & Hewga-CCS (15) & $34 / \mathrm{F}$ & Toe & Type 2 & Yes \\
\hline 15 & Senju-CCS (16) & NA & NA & Type 1 & NA \\
\hline 16 & RSAR001 (present study) & $43 / \mathrm{M}$ & Pleural effusion & Type 1 & Yes \\
\hline
\end{tabular}

F: Female; M: male; EWSR1- ATF1: Ewing sarcoma breakpoint region 1-activating transcription factor 1; NA, data not available.

be resected surgically. This contributes to the unfavorable 10year survival rate of CCS compared to the 5-year survival rate.

Recent progression in treatments including molecular targeted therapy and immunotherapy for several malignancies, especially for malignant melanoma (20) which has many similarities to CCS (21-25), has therefore attracted considerable attention for CCS. Although a number of reports indicate the possible efficacy of new therapeutic agents against CCS (23-29), most are case reports of single cases or a very small number of cases. Therefore, establishing the evidence of efficacy of these agents against CCS, both in basic research and clinically are required. The RSAR001 cell line can be expected to be useful for investigating the efficacy of antitumor agents against CCS both in vitro and in vivo. 

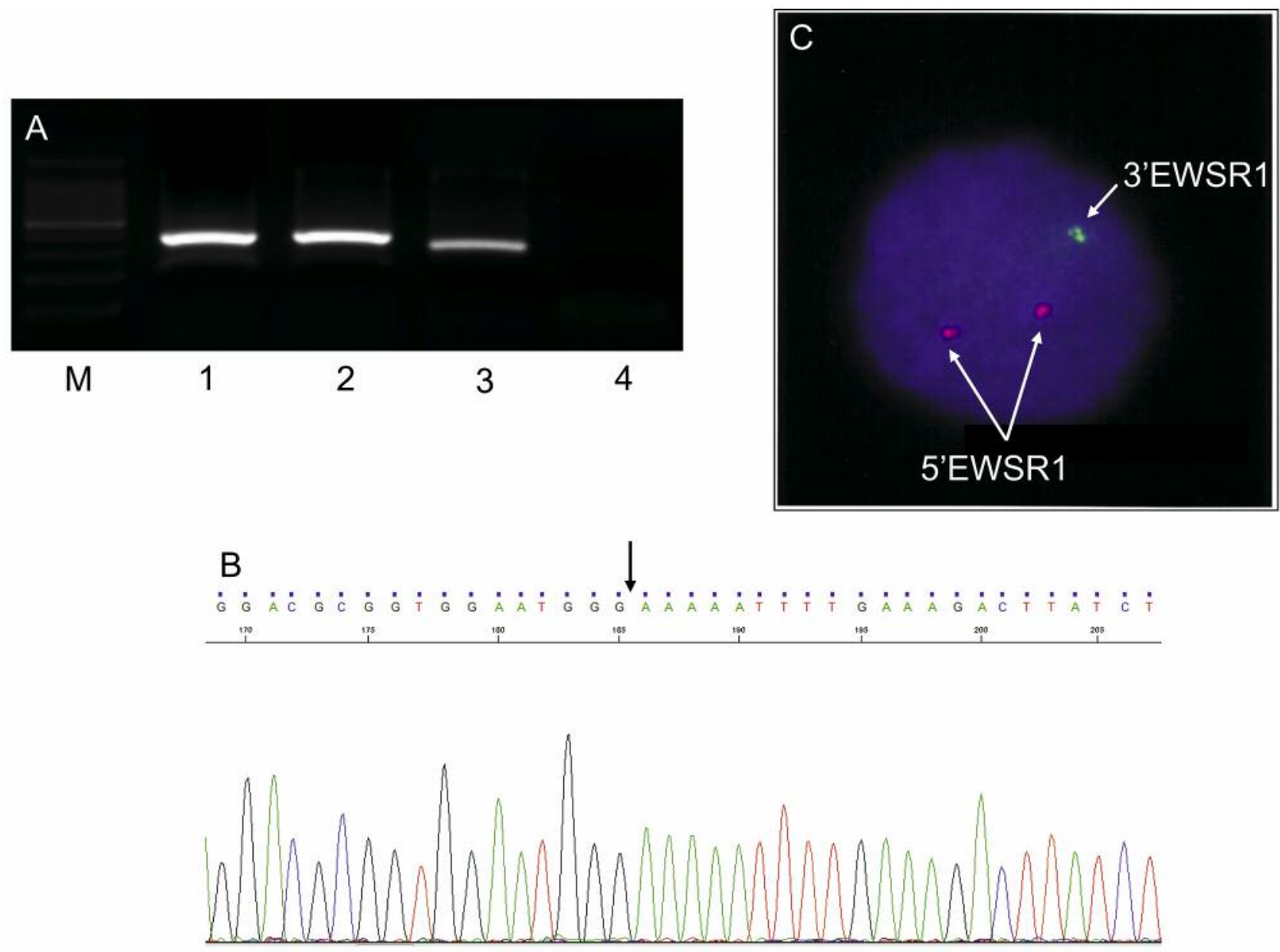

Figure 6. A: Reverse transcription-polymerase chain reaction amplification of Ewing sarcoma breakpoint region 1-activating transcription factor 1 (EWSR1-ATF1) chimeric fusion gene transcripts from RSAR001 cells. M, Marker (100-bp DNA ladder); lane 1, RSAR001; lane 2, EWSR1-ATF1 type-1 positive control; lane 3, EWSR1-ATF1 type-2 positive control; lane 4, negative control. B: Direct sequencing analysis showed a junction between EWSR1 exon 8 and ATF1 exon 4 (confirming EWSR1-ATF1 type 1). C: Fluorescence in-situ hybridization analysis showed the split signal of the EWSR1 gene in 100/100 cells (arrows).

\section{Conclusion}

The RSAR001 cell line established in the present study will prove useful for investigating biological behaviors and developing new therapies against CCS.

\section{Conflicts of Interest}

The Authors state that they have no conflicts of interest to declare in regard to this study.

\section{Funding}

This research was supported in part by a Grant-in-Aid for Young Scientists (B) (no. 25861331) from the Japan Society for the Promotion of Science (JSPS).

\section{References}

1 Antonescu CR: Clear cell sarcoma of soft tissue. In: WHO Classification of Tumours of Soft Tissue and Bone, Fourth Edition. Fletcher CDM, Bridge JA, Hogendoorn PCW and Mertens F (eds.). Lyon: IARC Press, pp. 221-222, 2013.

2 Goldblum JR, Folpe AL and Weiss SW: Clear cell sarcoma of soft parts. In: Enzinger and Weiss's Soft-Tissue Tumors, Sixth Edition. Goldblum JR, Folpe AL and Weiss SW (eds.). Philadelphia: Elsevier, pp. 886-894, 2014.

3 Epstein AL, Martin AO and Kempson R: Use of a newly established human cell line (SU-CCS-1) to demonstrate the relationship of clear cell sarcoma to malignant melanoma. Cancer Res 44: 1265-1274, 1984.

4 Sonobe H, Furihata M, Iwata J, Ohtsuki Y, Mizobuchi H, Yamamoto $\mathrm{H}$ and Kumano $\mathrm{O}$ : Establishment and characterization of a new human clear-cell sarcoma cell-line, HS-MM. J Pathol 169: 317-322, 1993. 
5 Takenouchi T, Ito K, Kazama T and Ito M: Establishment and characterization of a clear-cell sarcoma (malignant melanoma of soft parts) cell line. Arch Dermatol Res 286: 254-260, 1994.

6 Brown AD, Lopez-Terrada D and Denny C and Lee KA: Promoters containing ATF-binding sites are de-regulated in cells that express the EWS/ATF1 oncogene. Oncogene 10: 1749-1756, 1995.

7 Liao SK, Perng YP, Lee LA, Chang KS, Lai GM, Wong E and Ho YS: Newly established MST-1 tumour cell line and tumourinfiltrating lymphocyte culture from a patient with soft tissue melanoma (clear cell sarcoma) and their potential applications to patient immunotherapy. Eur J Cancer 32A: 346-356, 1996.

8 Hiraga H, Nojima T, Abe S, Yamashiro K, Yamawaki S, Kaneda $\mathrm{K}$ and Nagashima K: Establishment of a new continuous clear cell sarcoma cell line. Morphological and cytogenetic characterization and detection of chimaeric EWS/ATF1 transcripts. Virchows Arch 431: 45-51, 1997.

9 Moritake H, Sugimoto T, Asada Y, Yoshida MA, Maehara Y, Epstein AL and Kuroda H: Newly established clear cell sarcoma (malignant melanoma of soft parts) cell line expressing melanomaassociated Melan-A antigen and overexpressing C-MYC oncogene. Cancer Genet Cytogenet 135: 48-56, 2002.

10 Schaefer KL, Wai DH, Poremba C, Korsching E, van Valen F, Ozaki T, Boecker $\mathrm{W}$ and Dockhorn-Dworniczak B: Characterization of the malignant melanoma of soft-parts cell line GG-62 by expression analysis using DNA microarrays. Virchows Arch 440: 476-484, 2002.

11 Crnalic S, Panagopoulos I, Boquist L, Mandahl N, Stenling R and Löfvenberg R: Establishment and characterization of a human clearcell sarcoma model in nude mice. Int J Cancer 101: 505-511, 2002.

12 Jishage M, Fujino T, Yamazaki Y, Kuroda H and Nakamura T: Identification of target genes for EWS/ATF-1 chimeric transcription factor. Oncogene 22: 41-49, 2003.

13 Schaefer KL, Brachwitz K, Wai DH, Braun Y, Diallo R, Korsching E, Eisenacher M, Voss R, Van Valen F, Baer C, Selle B, Spahn L, Liao SK, Lee KA, Hogendoorn PC, Reifenberger G, Gabbert HE and Poremba C: Expression profiling of $\mathrm{t}(12 ; 22)-$ positive clear cell sarcoma of soft-tissue cell lines reveals characteristic up-regulation of potential new marker genes including ERBB3. Cancer Res 64: 3395-3405, 2004.

14 Davis IJ, Kim JJ, Ozsolak F, Widlund HR, Rozenblatt-Rosen O and Granter SR, Du J, Fletcher JA, Denny CT, Lessnick SL, Linehan WM, Kung AL and Fisher DE: Oncogenic MITF dysregulation in clear cell sarcoma: defining the MiT family of human cancers. Cancer Cell 9: 473-484, 2006.

15 Outani H, Tanaka T, Wakamatsu T, Imura Y, Hamada K, Araki $\mathrm{N}$, Itoh $\mathrm{K}$, Yoshikawa $\mathrm{H}$ and Naka $\mathrm{N}$ : Establishment of a novel clear-cell sarcoma cell line (Hewga-CCS), and investigation of the antitumor effects of pazopanib on Hewga-CCS. BMC Cancer 14: 455, 2014.

16 Nakai T, Imura Y, Tamiya H, Yamada S, Nakai S, Yasuda N, Kaneko K, Outani H, Takenaka S, Hamada K, Myoui A, Araki N, Ueda T, Itoh $\mathrm{K}$, Yoshikawa $\mathrm{H}$ and Naka $\mathrm{N}$ : Trabectedin is a promising antitumor agent potentially inducing melanocytic differentiation for clear cell sarcoma. Cancer Med 6: 2121-2130, 2017.

17 Ito M, Hiramatsu H, Kobayashi K, Suzue K, Kawahata M, Hioki K, Ueyama Y, Koyanagi Y, Sugamura K, Tsuji K, Heike T and Nakahata T: NOD/SCID/gamma(c)(null) mouse: An excellent recipient mouse model for engraftment of human cells. Blood 100: 3175-3182, 2002.
18 Antonescu CR, Tschernyavsky SJ, Woodruff JM, Jungbluth AA, Brennan MF and Ladanyi M: Molecular diagnosis of clear cell sarcoma: detection of EWS-ATF1 and MITF-M transcripts and histopathological and ultrastructural analysis of 12 cases. J Mol Diagn 4: 44-52, 2002.

19 Bianchi G, Charoenlap C, Cocchi S, Rani N, Campagnoni S, Righi A, Frisoni T and Donati DM: Clear-cell sarcoma of soft tissue: A retrospective review and analysis of 31 cases treated at Istituto Ortopedico Rizzoli. Eur J Surg Oncol 40: 505-510, 2014.

20 Atkinson V: Recent advances in malignant melanoma. Intern Med J 47: 1114-1121, 2017.

21 Negri T, Brich S, Conca E, Bozzi F, Orsenigo M, Stacchiotti S, Alberghini M, Mauro V, Gronchi A, Dusio GF, Pelosi G, Picci P, Casali PG, Pierotti MA and Pilotti S: Receptor tyrosine kinase pathway analysis sheds light on similarities between clear-cell sarcoma and metastatic melanoma. Genes Chromosomes Cancer 51: 111-126, 2012.

22 Stacchiotti S, Marrari A, Dei Tos AP and Casali PG: Targeted therapies in rare sarcomas: IMT, ASPS, SFT, PEComa, and CCS. Hematol Oncol Clin North Am 27: 1049-1061, 2013.

23 Goldberg JM, Fisher DE, Demetri GD, Neuberg D, Allsop SA, Fonseca C, Nakazaki Y, Nemer D, Raut CP, George S, Morgan JA, Wagner AJ, Freeman GJ, Ritz J, Lezcano C, Mihm M, Canning C, Hodi FS and Dranoff G: Biologic Activity of autologous, granulocyte-macrophage colony-stimulating factor secreting alveolar soft-part sarcoma and clear-cell sarcoma vaccines. Clin Cancer Res 21: 3178-3186, 2015.

24 Tazzari M, Palassini E, Vergani B, Villa A, Rini F, Negri T, Colombo C, Crippa F, Morosi C, Casali PG, Pilotti S, Stacchiotti S, Rivoltini L and Castelli C: Melan-A/MART-1 immunity in a EWS-ATF 1 translocated clear-cell sarcoma patient treated with sunitinib: A case report. BMC Cancer 15: 58, 2015.

25 Marcrom S, De Los Santos JF and Conry RM: Complete response of mediastinal clear cell sarcoma to pembrolizumab with radiotherapy. Clin Sarcoma Res 7: 14, 2017.

26 Stacchiotti S, Grosso F, Negri T, Palassini E, Morosi C, Pilotti $\mathrm{S}$, Gronchi A and Casali PG: Tumor response to sunitinib malate observed in clear-cell sarcoma. Ann Oncol 21: 1130-1131, 2010.

27 Mir O, Boudou-Rouquette $\mathrm{P}$ and Larousserie F, Babinet A, Dumaine V, Anract P and Goldwasser F: Objective response to sorafenib in advanced clear-cell sarcoma. Ann Oncol 23: 807809, 2012.

28 Protsenko SA, Semionova AI, Komarov YI, Aleksakhina SN, Ivantsov AO, Iyevleva AG and Imyanitov EN: BRAF-mutated clear cell sarcoma is sensitive to vemurafenib treatment. Invest New Drugs 33: 1136-1143, 2015.

29 Schöffski P, Wozniak A, Casali PG, Rutkowski P, Blay JY, Lindner LH, Strauss SJ, Anthoney A, Duffaud F, Richter S, Grünwald V, Leahy MG, Reichardt P, Sufliarsky J, van der Graaf WT, Sciot R, Debiec-Rychter M and van Cann T, Marréaud S, Lia M, Raveloarivahy T, Collette L and Bauer S: Activity and safety of crizotinib in patients with advanced clear cell sarcoma with MET alterations. European Organization for Research and Treatment of Cancer phase 2 trial 90101 "CREATE". Ann Oncol 28: 3000-3008, 2017. 